\title{
Attempts to Cool Pig Oocytes
}

\author{
Hajime Miyamoto, Eimei Sato and Takehiko Ishibashi \\ Department of Animal Science, Faculty of Agriculture, \\ Kyoto University, Kyoto-shi 606
}

(Received May 6, 1987)

\begin{abstract}
The present study was carried out to clarify the tolerance of pig oocytes toward cooling to temperatures above freezing. Oocytes at the germinal vesicle stage were recovered from ovaries. Oocytes at $30^{\circ} \mathrm{C}$ were cooled at 0.5 or $3^{\circ} \mathrm{C} / \mathrm{min}$ from $30^{\circ} \mathrm{C}$ to 0,10 and $20^{\circ} \mathrm{C}$, and held for $0.1-60 \mathrm{~min}$ at these temperatures. They were then cultured by the microdrop method at $37^{\circ} \mathrm{C}$ for $40-43 \mathrm{hr}$ in $5 \% \mathrm{CO}_{2}$ in air. Both before cooling, and after the oocytes were cooled to 0,10 and $20^{\circ} \mathrm{C}$ at $0.5^{\circ} \mathrm{C} / \mathrm{min}$, the proportion of oocytes maturing to metaphase II during culture was $54,0,0$, and $18 \%$, respectively. The cooling rate of $3^{\circ} \mathrm{C} / \mathrm{min}$ was more damaging to oocytes cooled to $20^{\circ} \mathrm{C}$ than that of $0.5^{\circ} \mathrm{C} / \mathrm{min}$. Holding for $60 \mathrm{~min}$ at $20^{\circ} \mathrm{C}$ decreased the proportion of oocytes maturing to metaphase II, whereas holding for $60 \mathrm{~min}$ at $30^{\circ} \mathrm{C}$ had no effect. The addition of cryoprotectants to the phoshate-buffered solution showed no adverse effects on the tolerance of cooled oocytes. These results indicate that pig oocytes at the germinal vesicle stage appear to be extremely sensitive toward cooling.

Jpn. J. Zootech. Sci., 59 (4) : 329-334, 1988
\end{abstract}

Key words : pig oocytes, cooling, above freezing, sensitivity

Since the first successful preservation of mouse embryos at low temperatures ${ }^{11}$, the deep freezing of embryos has now been achieved in a number of farm and laboratory animals ${ }^{2)}$. However, pig embryos have not been frozen successfully to date ${ }^{2,3)}$ and less attention has been devoted to the low temperature preservation of pig embryos compared to cattle embryos. Pig embryos survived when cooled to $15-20^{\circ} \mathrm{C}$, whereas embryos cooled to $0-10^{\circ} \mathrm{C}$ died ${ }^{4,5}$. In contrast, recently it has been shown that pig embryos have survived af ter cooling to $-5^{\circ} \mathrm{C}$ and being cultured in vitro ${ }^{6}$.

Instead of the greater difficulty of obtaining a large number of embryos from farm animals, many oocytes can be obtained easily from ovarian follicles and are available for experimentation. Recently it has been reported that a high proportion of bovine oocytes at the germinal vesicle stage can mature in vitro to metaphase II after cooling to $4^{\circ} \mathrm{C}^{7)}$.

In a preliminary paper, we examined the susceptibility of pig oocytes to cooling to temperatures above freezing ${ }^{8)}$. The present study reports in detail all the experiments to clarify the tolerance of pig oocytes to cooling to temperatures around $0^{\circ} \mathrm{C}$.

\section{Meterials and Methods}

\section{Oocyte collection}

Pig oocytes were obtained from prepubertal gilts of Landrace, 6-7 months old, at Jpn. J. Zootech. Sci., 59 (4) : 329-334, 


\section{MiYamoto, Sato and Ishibashi}

a slaughterhouse. The ovaries were transported to our laboratory in a physiological saline solution at $30-35^{\circ} \mathrm{C}$. The oocytes at the germinal vesicle stage were liberated from follicles $\left(2-5 \mathrm{~mm}\right.$ in diameter) with a needle at $30-35^{\circ} \mathrm{C}$.

Suspension solution and cryoprotectants

The suspension solution used for the collection of oocytes was a modified DULBECCO's phosphate-buffered saline ${ }^{97}$ supplemented with a $20 \%$ heat-inactivated fetal calf serum (PBS). In each experiment, the oocytes with corona cells from 2 to 4 females were used. The oocytes were washed twice with fresh PBS, and 15-30 oocytes were pipetted into each test-tube $(10 \times 100 \mathrm{~mm})$ containing $0.2 \mathrm{ml}$ PBS at $30^{\circ} \mathrm{C}$. In some experiments the oocytes were placed into test-tubes containing $0.2 \mathrm{ml} 0.5 \mathrm{M}$ sucrose, $1.5 \mathrm{M}$ dimethyl sulphoxide (DMSO) or $1.5 \mathrm{M}$ glycerol in PBS.

Cooling and recovery of cooled oocytes

Except for the samples held at $30^{\circ} \mathrm{C}$, the remaining samples were initiated into the cooling process immediately after the oocytes recovered from ovaries were transferred into a test-tube at $30^{\circ} \mathrm{C}$. The samples were cooled at 0.5 or $3^{\circ} \mathrm{C} / \mathrm{min}$ from $30^{\circ} \mathrm{C}$ to 0 , 10 and $20^{\circ} \mathrm{C}$. Immediately upon cooling to these temperatures, the oocytes were recovered in a watch glass and washed several times with the culture medium at room temperature.

In some experiments the oocytes were held for $0.1,20$ and $60 \mathrm{~min}$ at $0-30^{\circ} \mathrm{C}$ before recovery in a watch glass at room temperature. The holding time at $30^{\circ} \mathrm{C}$ means the duration incubated at $30^{\circ} \mathrm{C}$ after the oocytes, recovered from the ovaries, were transferred into a test-tube at $30^{\circ} \mathrm{C}$.

\section{Culture}

After the oocytes were washed, they were cultured by the microdrop method in a modified Krebs-Ringer bicarbonate medium ${ }^{10}$ supplemented with a $20 \%$ heatinactivated fetal calf serum at $37^{\circ} \mathrm{C}$ for $40-43 \mathrm{hr}$ in $5 \% \mathrm{CO}_{2}$ in air.

\section{Survival assay}

After culture, the oocytes were mounted on slides and fixed in acetic acid-ethanol (1:3) for 4-7 days. Then they were stained with aceto-orcein and examined for maturation. The viability of the cooled oocytes was assessed by their ability to mature to metaphase II from the germinal vesicle stage during culture. Experiments were replicated 2-5 times and the data were analyzed for statistical significance using an $\chi^{2}$ test.

\section{Results}

Before cooling or after oocytes at the germinal vesicle stage without cryoprotectant were cooled to 0,10 and $20^{\circ} \mathrm{C}$ at $0.5^{\circ} \mathrm{C} / \mathrm{min}$, the proportion of oocytes matured to metaphase II during culture was 54, 0, 0 and 18\%, respectively (Table 1 ). In the next experiments the oocytes were cooled at $3^{\circ} \mathrm{C} / \mathrm{min}$. Before cooling or af ter having been cooled to 0,10 and $20^{\circ} \mathrm{C}$ at $3^{\circ} \mathrm{C} / \mathrm{min}$, the rate of maturation was $49,0,0$ and $3 \%$, respectively (Table 1 ). The rate $(3 \%)$ of maturation after having been cooled at $3^{\circ} \mathrm{C} /$ min to $20^{\circ} \mathrm{C}$ was lower than that $(18 \%)$ of oocytes cooled at $0.5^{\circ} \mathrm{C} / \mathrm{min}(\mathrm{P}<0.01)$. 
Table 1. The proportion of pig oocytes at the germinal vesicle stage matured to metaphase II during culture after cooled at 0.5 or $3^{\circ} \mathrm{C} / \mathrm{min}$ to temperatures above freezing

\begin{tabular}{|c|c|c|c|}
\hline $\begin{array}{l}\text { Cooling } \\
\text { rate } \\
\left({ }^{\circ} \mathrm{C} / \mathrm{min}\right)\end{array}$ & $\begin{array}{l}\text { Minimum } \\
\text { temperature } \\
\left({ }^{\circ} \mathrm{C}\right)\end{array}$ & $\begin{array}{l}\text { No. of oocytes } \\
\text { recovered } \\
\text { after cooling }\end{array}$ & $\begin{array}{l}\text { \% of oocytes } \\
\text { matured to } \\
\text { metaphase II } \\
\text { during culture }\end{array}$ \\
\hline \multirow{4}{*}{$0.5^{*}$} & Before cooling & 81 & 54 \\
\hline & 20 & 85 & 18 \\
\hline & 10 & 74 & 0 \\
\hline & 0 & 77 & 0 \\
\hline \multirow{4}{*}{$3^{*}$} & Before cooling & 57 & 49 \\
\hline & 20 & 90 & 3 \\
\hline & 10 & 82 & 0 \\
\hline & 0 & 66 & 0 \\
\hline
\end{tabular}

* Experiments were carried out independently.

Immediately upon cooling to 0,10 and $20^{\circ} \mathrm{C}$, the oocytes were recovered and washed with culture medium at room temperature before culture.

Table 2. The proportion of pig oocytes at the germinal vesicle stage matured to metaphase II during culture after cooling in the presence of cryoprotectants

\begin{tabular}{|c|c|c|c|}
\hline Cryoprotectant & $\begin{array}{l}\text { Minimum } \\
\text { temperature } \\
\left({ }^{\circ} \mathrm{C}\right)\end{array}$ & $\begin{array}{l}\text { No. of oocytes } \\
\text { recovered } \\
\text { after cooling }\end{array}$ & $\begin{array}{l}\text { \% of oocytes } \\
\text { matured to } \\
\text { metaphase II } \\
\text { during culture }\end{array}$ \\
\hline \multirow{3}{*}{$\begin{array}{l}\text { Without } \\
\text { cryoprotectant }\end{array}$} & Before cooling & 87 & 51 \\
\hline & 20 & 78 & 15 \\
\hline & 10 & 71 & 0 \\
\hline \multirow{3}{*}{$1.5 \mathrm{M} \mathrm{DMSO}$} & Before cooling & 73 & 48 \\
\hline & 20 & 68 & $?$ \\
\hline & 10 & 79 & 0 \\
\hline \multirow{3}{*}{$1.5 \mathrm{M}$ glycerol } & Before cooling & 82 & 55 \\
\hline & 20 & 85 & 18 \\
\hline & 10 & 79 & 0 \\
\hline \multirow{3}{*}{$0.5 \mathrm{M}$ sucrose } & Before cooling & 92 & 56 \\
\hline & 20 & 80 & 20 \\
\hline & 10 & 63 & 0 \\
\hline
\end{tabular}

The oocytes were cooled at $0.5^{\circ} \mathrm{C} / \mathrm{min}$ from $30^{\circ} \mathrm{C}$ to various minimun temperatures. Immediately upon cooling to 10 and $20^{\circ} \mathrm{C}$, the oocytes were recovered and washed with culture medium at room temperature before culture.

As shown in Table 2, all the cryoprotectants (sucrose, DMSO and glycerol) examined had no adverse effects on the sensitivity of oocytes to cooling damage.

As shown in Table 3, the proportion of oocytes matured to metaphase II after being held for $0.1,20$ and $60 \mathrm{~min}$ at $30^{\circ} \mathrm{C}$ was 46,52 and $41 \%$, respectively. By 
Table 3. The proportion of pig oocytes at the germinal vesicle stage matured to metaphase II during culture after cooling and holding for $0.1-60 \mathrm{~min}$ at various minimum temperatures

\begin{tabular}{cccc}
\hline \hline $\begin{array}{c}\text { Minimum } \\
\text { temperature } \\
\left({ }^{\circ} \mathrm{C}\right)\end{array}$ & $\begin{array}{l}\text { Holding } \\
\text { time } \\
(\mathrm{min})\end{array}$ & $\begin{array}{l}\text { No. of oocytes } \\
\text { recovered } \\
\text { after cooling }\end{array}$ & $\begin{array}{l}\text { \% of oocytes } \\
\text { matured to } \\
\text { metaphase II } \\
\text { during culture }\end{array}$ \\
\hline 30 & 0.1 & 65 & 46 \\
& 20 & 75 & 52 \\
20 & 60 & 61 & 41 \\
\hline & 0.1 & 22 & 21 \\
10 & 20 & 66 & 12 \\
\hline 0 & 60 & 81 & 1 \\
\hline
\end{tabular}

The oocytes were cooled at $0.5^{\circ} \mathrm{C} / \mathrm{min}$ from $30^{\circ} \mathrm{C}$ to various minimum temperatures and held for $0.1-60 \mathrm{~min}$.

The holding time at $30^{\circ} \mathrm{C}$ means the duration incubated at $30^{\circ} \mathrm{C}$ after the oocytes recovered from ovaries were transferred into test-tube at $30^{\circ} \mathrm{C}$.

contrast, the rate of maturation was 21,12 and $1 \%$ when held for $0.1,20$ and 60 min at $20^{\circ} \mathrm{C}$. Hence, holding time of $60 \mathrm{~min}$ at $20^{\circ} \mathrm{C}$ decreased the survival of oocytes, whereas holding time at $30^{\circ} \mathrm{C}$ had no effects.

\section{Discussion}

In the present study, pig oocytes at the germinal vesicle stage, cooled to 0 and $10^{\circ} \mathrm{C}$, completely lost their ability to mature to metaphase II during culture. Attempts of slow cooling were unsuccessful. By contrast, when cattle oocytes at the germinal vesicle stage were cooled to $4^{\circ} \mathrm{C}, 62 \%$ of the oocytes matured to metaphase II during culture and $34 \%$ of the oocytes after being held for $6 \mathrm{hr}$ at $4^{\circ} \mathrm{C}^{7}$. The sensitivity of pig oocytes to cooling appears to be even more marked than that of cattle oocytes.

Deep freezing of cattle embryos is now well established and commonly employed in cattle breeding, whereas no pig embryos at 8-cell and blastocyst stages survived even after cooling to $0-10^{\circ} \mathrm{C}^{4,5)}$. These results show that there are differences between cattle and pig in the responses of embryos to cooling as observed in oocytes. Recently it has been shown that Days-5-6 pig embryos survived after cooling to $-5^{\circ} \mathrm{C}$ and culturing in vitro ${ }^{6)}$. Furthermore, a few of the fully expanded pig blastocysts could hatch from the zona pellucida after deep freezing and culturing, but none survived to term after transplantation ${ }^{11}$. Considerable progress in the preservation of pig embryos and oocytes will be made through experiments designed to study an understanding of the nature of differences between species.

The reasons for the extreme sensitivity of pig oocytes and embryos to cooling are still obscure. It has been shown that triacylglycerol is the major lipid component of 


\section{Attempts to Cool Pig Oocytes}

pig oocytes followed by cholesterol and diacylglycerol and that while the lipid composition of pig oocytes is similar to that of other cell types, there are some striking differences ${ }^{12}$. Since during cooling and warming there was an abundant loss of intracellular lipids in the pig embryos, the damage caused to pig embryos during cooling may be associated with lipid phase changes within the cell membranes ${ }^{2}$. Further studies are necessary for the cryopreservation of pig embryos and oocytes.

\section{Acknowledgement}

This work was supported by a grant-in-aid for scientific research from the Ministry of Education, Science and Culture, Japan.

\section{References}

1) Whittingham, D.G., S.P. Leibo and P. Mazur, Science, 178:411-414. 1972.

2) Polge, C., in The Freezing of Mammalian Embryos (Elliott, K. and J. Whelan, eds.) 3-13. Elsevier, Amsterdam. 1977.

3) Polge, C., in Control of Pig Reproduction (Cole, D.J.A. and G.R. FoxcrofT, eds.) 277-291. Butterworths, London. 1982.

4) Wilmut, I., Unpublished.

5) Polge, C., I. Wilmut and L.E.A. Rowson, Unpublished.

6) Soma, T., T. KoJima and N. Oguri, Unpublished.

7) Aoyagi, Y., Y. Iwazumi, H. Wachi, M. Furudate, K. Fuzir, Y. Fukui and H. Ono, Jpn. J. Anim. Reprod., 32: 138-143. 1986.

8) Miyamoto, H., E. Sato and T. Ishibashi, Jpn. J. Anim. Reprod. Tech., 9: 7-9. 1987.

9) Whittingham, D.G., Nature, $233:$ 125-126. 1971.

10) Whittingham, D.G., J. Reprod. Fert., Suppl. 14: 7-21. 1971.

11) Polge, C., J. Reprod. Fert., Suppl. 33: 93-100. 1985.

12) Homa, S.T., C. Racowsky and R.W. McGaughey, J. Reprod. Fert., 77 : 425-434. 1986. 


\title{
ブタ卵胞卵の冷却の試み
}

\author{
宮本 元・佐藤英明・石橋武彦 \\ 京都大学農学部, 京都市 606
}

ブタ期胞眨を 0-20足の温度に冷却した之きの生存性 を明らかにするために，本実験を行なった，直径 2-5 mm の卵胞から卵核胞期の卵胞卵を採取し，20\%の牛胎児 血清を含む修正りン酸緩衝液 $\left(30^{\circ} \mathrm{C}\right)$ に浮遊させた。卵 胞卵を 0.5 または $3^{\circ} \mathrm{C} /$ 分の速度で 0,10 および $20^{\circ} \mathrm{C} に$ 冷却し，これらの温度に到達直後，または $0.1 ， 20$ およ び 60 分間保った後に室温下の培養液で洗浄後，培養し た。留胞卵を，冷却前または $0.5^{\circ} \mathrm{C} /$ 分の速度で 0,10 ， $20^{\circ} \mathrm{C}$ に冷却し，ただちに室温下の培養液で洗浄後培養 した場合、卵核胞期から第 2 成熟分裂中期に移行した割 合はそれぞれ $54 ， 0 ， 0$ およ゙ $18 \%$ であった。また卵胞 卵を $3^{\circ} \mathrm{C} /$ 分の速度で $0 ， 10 ， 20^{\circ} \mathrm{C}$ に阾却した場合，第 2 成愁分裂中期に移行した割合はそれぞれ $0 ， 0$ および
$3 \%$ であり，20 $2{ }^{\circ} \mathrm{C}$ に冷却した卵の移行率は $3^{\circ} \mathrm{C} /$ 分より 0.5 ${ }^{\circ} \mathrm{C} /$ 分の方が高かった. $30^{\circ} \mathrm{C}$ で卵巣から採取した卵胞畉 を洗浄し小試験管に移した後, $30^{\circ} \mathrm{C} て ゙ 60$ 分間保持して も，培養後第 2 成熟分裂中期へ移行する割合は低下しな かったが， $20^{\circ} \mathrm{C}$ で 60 分間保持すると培養後の移行率は 低下した。 ジメチルスルフォキサイド，グリセロールお よびショ糖を添加してむ, 冷却された卵胞卵の生存性は 影響を受けなかった，以上の成績から，本研究におりる 実験条件下では卵核胞期のブタ卵胞卵を 0-10 $\mathrm{C}$ に冷却 すると死隇し，ブタ卵胞畉は冷却処理にきわわて弱いと 思われる。

日畜会報，59(4)：329-334，1988 